\title{
Long-term monitoring of marine turtle nests in northeastern Brazil
}

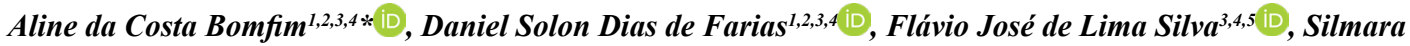 \\ Rossi $^{2}$ (D), Simone Almeida Gavilan ${ }^{2,3,4}$, Vinícius Gabriel da Silva Santana ${ }^{1,3}$ iD \& Cibele Soares Pontes ${ }^{1,6}$ (D) \\ ${ }^{1}$ Universidade Federal do Rio Grande do Norte, Programa de Doutorado em Desenvolvimento e Meio \\ Ambiente, Campus Universitário, Lagoa Nova, 59072-970, Natal, RN, Brasil. \\ ${ }^{2}$ Universidade Federal do Rio Grande do Norte, Centro de Biociências, Departamento de Morfologia, \\ Laboratório de Morfofisiologia de Vertebrados, Campus Universitário, Avenida Senador Salgado Filho, 3000, \\ Lagoa Nova, 59078-900, Natal, RN, Brasil. \\ ${ }^{3}$ Universidade do Estado do Rio Grande do Norte, Laboratório de Monitoramento de Biota Marinha, Projeto \\ Cetáceos da Costa Branca, Campus Central, 59600-000, Mossoró, RN, Brasil. \\ ${ }^{4}$ Centro de Estudos e Monitoramento Ambiental, Areia Branca, 59655-000, Natal, RN, Brasil. \\ ${ }^{5}$ Universidade do Estado do Rio Grande do Norte, Departamento de Turismo, Campus Natal, Av. Dr. João \\ Medeiros Filho, 3419, Potengi, 59104-200, Natal, RN, Brasil. \\ ${ }^{6}$ Universidade Federal do Rio Grande do Norte, Escola Agrícola de Jundiaí, Unidade Acadêmica Especializada \\ em Ciências Agrárias, Campus Macaíba, RN 160, Km 03, Distrito de Jundiai, Zona Rural, 59280-000, \\ Macaiba, RN, Brasil. \\ "Corresponding author: alinebonfim_7@hotmail.com
}

BOMFIM, A.C., FARIAS, D.S.D., SILVA, F.J.L., ROSSI, S., GAVILAN, S.A., SANTANA, V.G.S., PONTES, C.S. Long-term monitoring of marine turtle nests in northeastern Brazil. Biota Neotropica 21(3): e20201159. https://doi.org/10.1590/1676-0611-BN-2020-1159.

Abstract: This study monitored marine turtle nests in a region known as the Potiguar Basin, which stretches from the northern region of Rio Grande do Norte State $\left(5^{\circ} 4^{\prime} 1.15^{\prime \prime}\right.$ S, 36 4'36.41" W) to eastern Ceará State $\left(4^{\circ} 38^{\prime} 48.28^{\prime \prime}\right.$ S, 37²'52.08” W) in Brazil. We collected data from January 2011 to December 2019 to identify species of sea turtles that spawn in the basin, to analyze the nesting spatial-temporal pattern and nests characteristics, and to record effects of environmental and anthropic factors on nests. A field team examined sea turtle tracks and nests signs. Turtle clutches were monitored daily until hatchings emerged from the nests. We monitored nests of hawksbill (Eretmochelys imbricata; $\mathrm{n}=238$ ) and olive Ridley turtles (Lepidochelys olivacea; $\mathrm{n}=103$ ). The nesting season for E. imbricata occurred between December and May and for L. olivacea from March to August. Hawksbills had clutch size, incubation time, number of unhatched eggs, and dead hatchlings higher than olive Ridley turtles; nevertheless, they presented lower hatching success. Precipitation between 0 and $22 \mathrm{~mm}$ and relative humidity (RH) higher than $69 \%$ increased the hatching success rate for E. imbricata; however, rainfall above $11 \mathrm{~mm}$ and $\mathrm{RH} 64 \%$ had the same effect for L. olivacea. Signs of egg theft and human presence (e.g. vehicle traffic and plastic residues on the beach) were recorded and are considered threats to nests. The results of our long-term monitoring study in the Potiguar Basin provide basis for the implementation of mitigation measures and adoption of management policies at nesting beaches in this Brazilian region.

Keywords: Eretmochelys imbricata; Lepidochelys olivacea; spawn; hatching success; threats.

\section{Monitoramento de longo prazo de ninhos de tartarugas marinhas no nordeste do Brasil}

Resumo: Este estudo permitiu o monitoramento de ninhos de tartarugas marinhas em uma região conhecida como Bacia Potiguar, que se estende da região norte do Estado do Rio Grande do Norte (5 ${ }^{\circ}$ ' 1,15 "S, $36^{\circ} 4$ ' $36,41^{\prime}$ " $\mathrm{W}$ ) até o leste do Estado do Ceará ( $4^{\circ} 38^{\prime} 48,28^{\prime}$ 'S, $37^{\circ} 32$ '52,08” W), no Brasil. Coletamos dados de janeiro de 2011 a dezembro de 2019 com o objetivo de identificar as espécies de tartarugas marinhas que desovam na bacia, analisar o padrão espaço-temporal de nidificação, as características dos ninhos, e registrar os efeitos de fatores ambientais e antrópicos. Uma equipe de campo examinou rastros de tartarugas marinhas e sinais de ninhos. As ninhadas das tartarugas foram monitoradas diariamente até que os filhotes emergissem dos ninhos. Monitoramos 
ninhos de tartarugas-de-pente (Eretmochelys imbricata; $\mathrm{n}=238$ ) e tartarugas-oliva (Lepidochelys olivacea; $\mathrm{n}$ =103). A época de nidificação para E. imbricata ocorreu entre dezembro e maio e para L. olivacea de março a agosto. Tartarugas-de-pente apresentaram maior tamanho das ninhadas, tempo de incubação, número de ovos não eclodidos e número de filhotes mortos quando comparado com tartarugas-oliva; no entanto, apresentaram menor sucesso de eclosão. Precipitação entre 0 e $22 \mathrm{~mm}$ e umidade relativa (UR) maior que $69 \%$ aumentaram a taxa de sucesso de eclosão para E. imbricata; entretanto, chuvas acima de $11 \mathrm{~mm}$ e UR 64\% tiveram o mesmo efeito para L. olivacea. Sinais de roubo de ovos e presença humana (por exemplo, tráfego de veículos e resíduos de plástico na praia) foram registrados e são considerados ameaças aos ninhos. Os resultados do nosso estudo de monitoramento de longo prazo na Bacia Potiguar fornecem base para a implementação de medidas de mitigação e adoção de políticas públicas em praias de desova nesta região brasileira.

Palavras-chave: Eretmochelys imbricata; Lepidochelys olivacea; spawn; hatching success; threats.

\section{Introduction}

Sea turtle species are distributed around the globe throughout tropical, subtropical, and temperate oceans, migrating to and from their nesting beaches. There are seven sea turtles species and five of which are found in Brazil, namely hawksbill turtle (Eretmochelys imbricata: Linnaeus 1766), olive Ridley turtle (Lepidochelys olivacea: Eschscholtz 1829), loggerhead turtle (Caretta caretta: Linnaeus 1758), leatherback turtle (Dermochelys coriacea: Linnaeus 1766), and green turtle (Chelonia mydas: Linnaeus 1758) (Santos et al. 2011). According to the Red List of Threatened Species of the International Union for Conservation of Nature, sea turtles are classified as critically endangered (E. imbricata), vulnerable (L. olivacea, C. caretta and D. coriacea), and endangered $(C$. mydas) (Seminoff 2004, Abreu-Grobois \& Plotkin 2008, Mortimer \& Donnelly 2008, Wallace et al. 2013, Casale \& Tucker 2017).

Sea turtles face many threats, and urban development and fisheries on the coast pose as the main ones, a condition that has continuously increased in last two decades (Carvalho et al. 2016). Incidental capture occurs in many fisheries in Brazil, leading to high mortality of adult females around nesting areas (Castilhos et al. 2011, Santos et al. 2011, Guebert et al. 2013). In the past, the hunting of females during nesting and the collection of turtle eggs for food reduced populations of hawksbill and olive Ridley sea turtles. For the hawksbill turtle, carapace commerce was the main threat (Castilhos et al. 2011, Marcovaldi et al. 2011).

In Brazil, sea turtles species use many important nesting areas. Hawksbill turtle nests mainly on the eastern coast of Rio Grande do Norte (RN) and the northern coast of Sergipe and Bahia. Olive Ridley turtle spawns on the southern coast of Alagoas and on the northern coast of Bahia. Loggerhead turtle nests on the coast in Sergipe and the northern coast of Bahia, Espírito Santo, and Rio de Janeiro. Leatherback turtle spawns on the coast of Piaui and the northern coast of Espírito Santo (Marcovaldi et al. 2007, Silva et al. 2007, Marcovaldi et al. 2011, Santos et al. 2011, Santana et al. 2016). Green turtles make their nests kilometers off the coast, on the Island of Trindade/ Espírito Santo, Atol das Rocas Biological Reserve/Rio Grande do Norte, and Fernando de Noronha Archipelago/Pernambuco (Moreira et al. 1995, Bellini \& Sanches 1996, Grossman et al. 2003).

Research conducted in different sites, considering regional environmental conditions and anthropogenic interaction, has revealed variation in nesting ecology, such as nesting season, clutch frequency, remigration intervals, size of nesting females, clutch size, incubation time, and hatching success (Richardson et al. 1999, Dornfeld et al. 2014, Santos et al. 2016, Chatting et al. 2018). In Brazil, studies have been carried out in the eastern portion of the coast of Rio Grande do Norte State (RN) to investigate the life cycle and nesting of sea turtles (Marcovaldi et al. 2007,
Santos 2008, Santos et al. 2013, Santos et al. 2016). However, knowledge on nesting of sea turtles on the northern coast of $\mathrm{RN}$ is scarce, as previous studies focused on the breeding activity of hawksbill and olive Ridley sea turtles (Souza-Junior 2014, Costa et al. 2016).

Knowledge on the nesting ecology of sea turtles is useful for their conservation (e.g. beach coverage, monitoring of nesting females and their nests). This study aimed to: (1) survey sea turtle species that nest on the northern coast of RN and eastern coast of Ceará, (2) analyze the spatial-temporal pattern of nesting and characteristics of nests, and (3) record the effects of environmental and anthropic factors on the nesting of species that spawn in the region.

\section{Materials and Methods}

\section{Study site}

This study was carried out on the coastal region in the Brazilian northeast, between the municipalities of Caiçara do Norte, Rio Grande do Norte (RN) (5'4'1 .15” S, 364'36.41” W) and Icapui, Ceará (CE) (4³8'48.28' S and 37'32'52.08' W), a region known as the Potiguar Basin (Figure 1). The study site comprises crystalline basement rocks (Soares et al. 2003) and sand beaches, with different geomorphological and environmental characteristics along the extension monitored (approximately $300 \mathrm{~km}$ long). The main economic activities in Icapuí are tourism, artisanal fishing, and saliniculture, while in Caiçara do Norte, artisanal or professional fishing (depending on the beach), wind energy, and gas/petroleum exploration are the main economic activities. The climate in the region is semi-arid with varied humidity, low rainfall, and two well-defined seasons: dry (between June and January), with strong winds, and rainy (from February to May) (Jimenez et al. 1999, Testa \& Bosence 1999, Souto 2009).

Since 2010, the Projeto Cetáceos da Costa Branca - Universidade do Estado do Rio Grande do Norte (PCCB-UERN) has conducted the Beach Monitoring Project in the Potiguar Basin (Projeto de Monitoramento de Praias da Bacia Potiguar-PMP-BP). The PMP-BP is part of an environmental constraint compliance enforced by the Instituto Brasileiro do Meio Ambiente e dos Recursos Naturais Renováveis IBAMA (Brazilian Institute of the Environment and Renewable Natural Resources) for oil exploration by PETROBRAS (Petróleo Brasileiro S.A.; agreement number 2500.005657510.2).

\section{Nesting ecology}

We evaluated breeding biology and spatial-temporal distribution of nests by the number of nests and the turtle eggs recorded between January 2011 


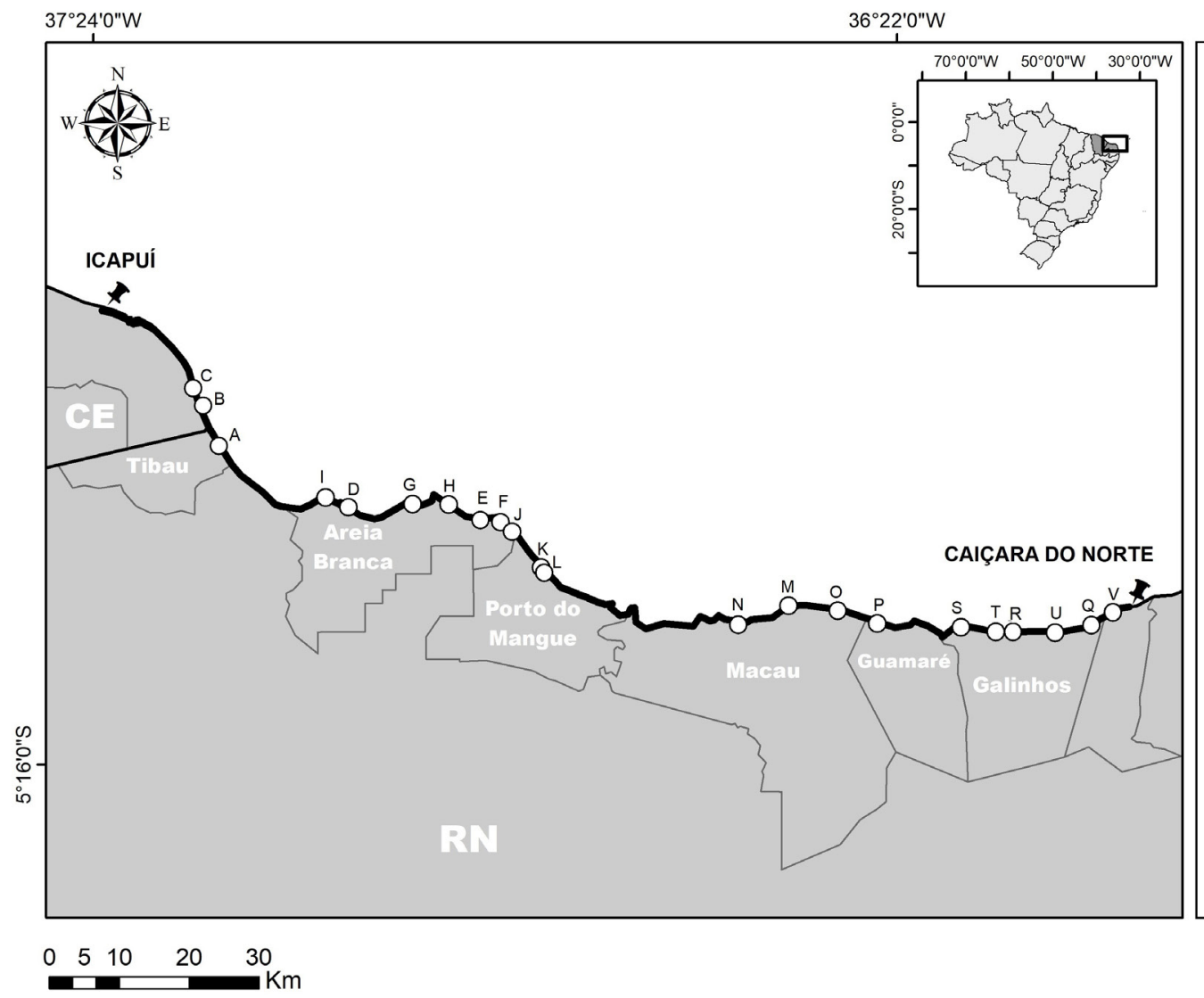

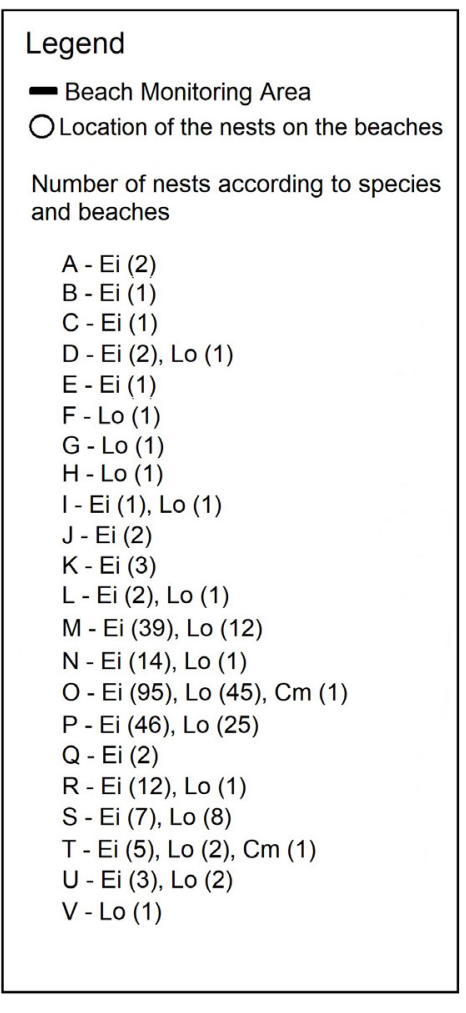

DATUM: SIRGAS 2000

Figure 1. Geographic distribution of the study site, Brazilian northeastern coast. (Ei) Eretmochelys imbricata, (Lo) Lepidochelys olivacea, (Cm) Chelonia mydas, (A) Emanuelas Beach, (B) Manibu Beach, (C) Peixe Gordo Beach, (D) Baixa Grande Beach, (E) Mel de Baixo Beach, (F) Ponta do Mel Beach, (G) Redonda Beach, (H) São Cristóvão Beach, (I) Paraíso Beach, (J) Pedra Grande Beach, (K) Porto do Mangue Beach, (L) Rosado Beach, (M) Costa da Ponta do Tubarão, (N) Pontal dos Anjos Beach, (O) Restinga de Diogo Lopes, (P) Minhoto Beach, (Q) Fazenda Beach, (R) Dunas Beach, (S) Galinhos Beach, (T) Galos Beach, (U) Catavento Beach, (V) Caiçara do Norte Beach.

and December 2019. During the daily monitoring, our field team examined sea turtle tracks, and if the place looked like a nest, the site was excavated to determine presence of a turtle clutch. The static function of GPS was used to determine the nest position and a wood stake was fixed next to each nest to indicate its location. Daily monitoring was carried out to record possible damage to nests caused by human and erosion or stake loss. Eggs from some nests were excavated and moved to other sites to protect from vehicles and high tides. The nests were opened after incubation time (approximately 60 days) or when the field team found hatchling tracks on the beach. Species were identified according to Pritchard \& Mortimer (2000). In this study, we analyzed characteristics of nests, types of nest site, nests depth, and distance from the highest tide line.

Characteristics of nests (from 2011 to 2019) adapted from Miller (1999): (a) clutch size: total number of eggs laid by turtles; (b) incubation time: from the day of egg laying until emergence of hatchlings, when we found tracks of hatchlings on the beach; (c) unhatched eggs: total number of unhatched eggs with no obvious embryo + unhatched eggs with obvious embryo; (d) dead hatchlings: total number of dead hatchlings found in nests; (e) live hatchlings: total number of live hatchlings found in nests + number of empty shells counted ( $>50 \%$ complete); and (f) hatching success $=($ total number of live hatchlings $/$ clutch size $) \times 100$.

Types of nest site (data from 2018 to 2019): defined as the distance of $50 \mathrm{~cm}$ from the nest center. The types were classified into three categories according to Santos et al. (2016): (a) vegetation, areas with herbaceous species; (b) open sand, presence of fine granular sand soil without any vegetation; and (c) sand slope, formations of sandbanks.

Nest depth (data from 2016 to 2019): measured at the bottom of the egg chamber after removal of nest contents according to Miller (1999).

Distance from the highest tide line (data from 2015 to 2019): measured according Santos et al. (2016) and defined as the distance from the nest to the mark of the highest tide, visualized as a line of marine detritus on the beach.

\section{Weather data}

Data on precipitation, relative humidity and air temperature for the study period was obtained from INMET (National Institute of Meteorology) (http://www.inmet.gov.br/portal/index.php?r=bdmep/ bdmep accessed 13 Feb 2020).

\section{Anthropogenic interaction with nests and nesting activity}

We collected information on threats for 108 months considering the observations during the monitoring of PCCB-UERN, which included signs of egg theft. We also monitored light pollution, defined as the introduction of artificially produced light into nesting areas, and signs of human presence (e.g. vehicle traffic, plastic residue found on the beach) according to Lopez et al. (2015) and Fernandes et al. (2016). 


\section{Statistical analyses}

Komolgorov-Smirnov and Levene tests were performed to verify distribution and homocedasticity, respectively. The Mann-Whitney test was used to compare results between E. imbricata and L. olivacea in terms of clutch size, incubation time, unhatched eggs, dead hatchlings, live hatchlings, and hatching success. Kruskal-Wallis and Bonferroni tests were applied to analyze spatial-temporal variations in the number of recorded nests.

The Kruskal-Wallis test was used to analyze the hatching success and incubation time during the months of the breeding season. The ANOVA and Kruskal-Wallis tests were performed to compare hatching success and incubation time between the nest sites. The Spearman rank correlation was used to correlate hatching success and incubation time with (1) depth nest, and (2) nest distance to the highest tide. We calculated the equation that represents the relation between hatching success and weather data (precipitation, relative humidity, and air temperature). The analyses were performed using IBM SPSS Statistics (version 20) and the results were considered significant at P-value $<0.05$.

\section{Results}

\section{Spatial-temporal distribution and characteristics of the examined nests}

We recorded 692 nests during 108 months (January 2011- December 2019), namely 238 of E. imbricata (34.39\%), 103 of L. olivacea (14.88\%), two of C. mydas ( $0.29 \%)$, and 349 of species that could not be identified (50.43\%). The non-identification occurred due to presence of unhatched eggs, egg removal by humans, erosion resulting in loss of nests, loss of wood stake fixed next to each nest to indicate its location, and absence of live or dead hatchlings whose could allow the species identification. Nests of green sea turtles, nests of non-identified species, and the nests transferred to protected areas accounted for $58.67 \%$ of the nests examined (406/692) and were excluded from the statistical analyses. Most nests of E. imbricata and L. olivacea were recorded between Macau/RN (207/341; 60.70\%) and Guamaré/RN (71/341; $20.82 \%$ ) along $46 \mathrm{~km}$ (Figure 2). There was significant statistical difference between the municipalities (Kruskal-Wallis test, $H 7=$ 42.476, $P<0.001)$ and the number of nests in Macau differed from other municipalities, except from Guamare (Bonferroni test). The nests of C. mydas were recorded in Restinga de Diogo Lopes, Macau/RN, on May 3, 2015 (70 eggs, incubation time $=48$ days, and hatching success $=81.43 \%)$ and in Galos Beach, Galinhos/RN, on March 21, 2017 (74 eggs, incubation time $=58$ days, and hatching success $=21.62 \%$ ). Details of all data are shown in Table 1.

There was significant statistical difference in number of nests of $E$. imbricata (Kruskal-Wallis test, $H 11=51.021, P<0.001$ ) and $L$. olivacea (Kruskal-Wallis test $H 11=38.323, P<0.001$ ) between the months. The nesting season occurred between December and May with a peak of the nesting activity recorded in March for E. imbricata $(\mathrm{n}=88,36.97 \%)$ and from March to August for L. olivacea ( $\mathrm{n}=33,32.04 \%$; Figure 3), with higher nesting activity in May.

Only the nests kept in situ and that completed the incubation time were included in the statistical analyses $(\mathrm{n}=278)$. Eretmochelys imbricata had higher clutch size (Mann-Whitney U test, $U=3.537, \mathrm{~N} 1$

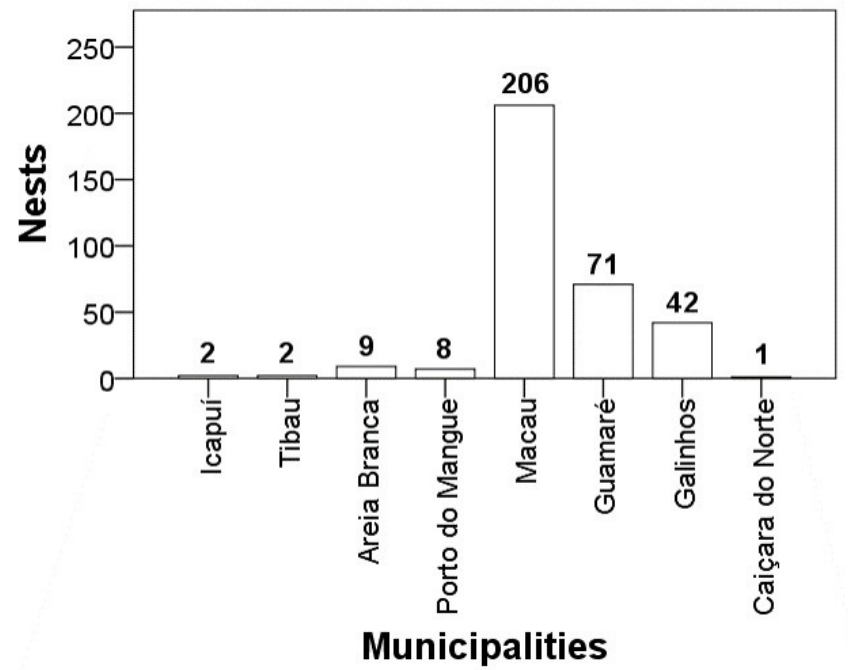

Figure 2. Number of nests of sea turtles (Eretmochelys imbricata and Lepidochelys olivacea) registered by municipalities in the Potiguar Basin, January 2011 - December 2019.

$=184, \mathrm{~N} 2=92, P<0.001)$, incubation time (Mann-Whitney $\mathrm{U}$ test, $U=4.404, \mathrm{~N} 1=165, \mathrm{~N} 2=84, P<0.001)$, number of unhatched eggs (Mann-Whitney U test, $U=5.671, \mathrm{~N} 1=184, \mathrm{~N} 2=92, P<0.001$ ), and dead hatchlings (Mann-Whitney $U$ test, $U=6.876, \mathrm{~N} 1=184, \mathrm{~N} 2=91$, $P=0.034$ ) compared to L. olivacea. The number of live hatchlings was similar between these species (Mann-Whitney U test; $U=6.895, \mathrm{~N} 1$ $=183, \mathrm{~N} 2=91, P=0.064)$ and hatching success for $E$. imbricata was lower than for L. olivacea (Mann-Whitney $\mathrm{U}$ test; $U=9.324 .5, \mathrm{~N} 1=$ 183, N2 = 92, $P=0.043$; Table 1).

\section{Hatching success}

The highest hatching success rate was recorded in December for $E$. imbricata $(67.07 \pm 27.95 \%, \mathrm{n}=7)$ and in June for L. olivacea $(79.17$ $\pm 21.69 \%, \mathrm{n}=14)$. There was no statistical difference (Kruskal-Wallis test, $E$. imbricata $H 5=4.066, P=0.540 ;$ L. olivacea $H 5=6.778, P=$ 0.238; Table 2).

The highest hatching success rate was recorded on sand slope for $E$. imbricata $(62.82 \pm 11.94 \%, \mathrm{n}=3)$ and under vegetation for $L$. olivacea $(84.28 \pm 20.89 \%, \mathrm{n}=4$; Table S1). The ANOVA and Mann-Whitney $\mathrm{U}$ tests revealed similarity of the hatching success rate between nest sites of E. imbricata and L. olivacea: $F(2,26)=0.145, P=0.865 ; U$ $=73.000, N 1=24, N 2=4, P=0.110$, respectively.

Nests $30-39 \mathrm{~cm}$ deep presented higher hatching success rate (E. imbricata $58.22 \pm 29.25 \%, \mathrm{n}=22$; and L. olivacea $56.28 \pm 29.53 \%, \mathrm{n}=20$ ). There was no correlation between nest depth and hatching success rate (Spearman rank correlation, E. imbricata $\mathrm{rs}=0.163, N=60, P=0.201 ;$ L. olivacea $\mathrm{rs}=$ $-0.018, N=33, P=0.922)$. All results on nest depth are shown in Table S2.

Nests found between 49 and $70 \mathrm{~m}$ from the highest tide line presented higher hatching success rate for E. imbricata $(57.78 \pm 37.09 \%$, $\mathrm{n}=4$; Spearman rank correlation, $\mathrm{rs}=-0.014, N=71, P=0.908)$ and between $5-25 \mathrm{~m}$ for L. olivacea $(62.51 \pm 31.77 \%, \mathrm{n}=40$; Spearman rank correlation, $\mathrm{rs}=0.055, N=47, P=0.712$ ) (Table S3).

\section{Incubation time}

January represented the highest incubation time for $E$. imbricata (58.94 \pm 2.14 days, $\mathrm{n}=16$ ), and March for L. olivacea $(59.5 \pm 0.71$ 
Monitoring of marine turtle nests

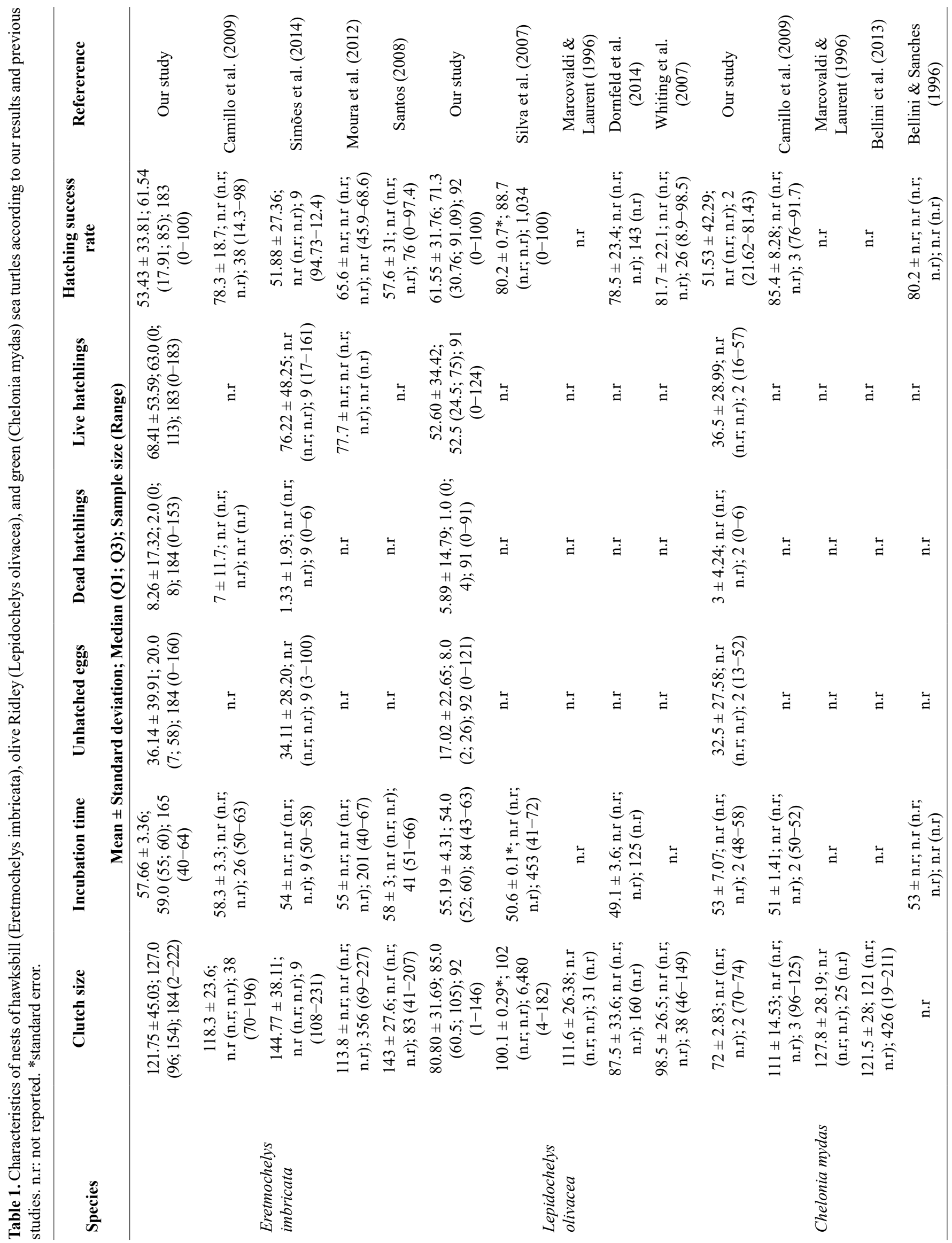




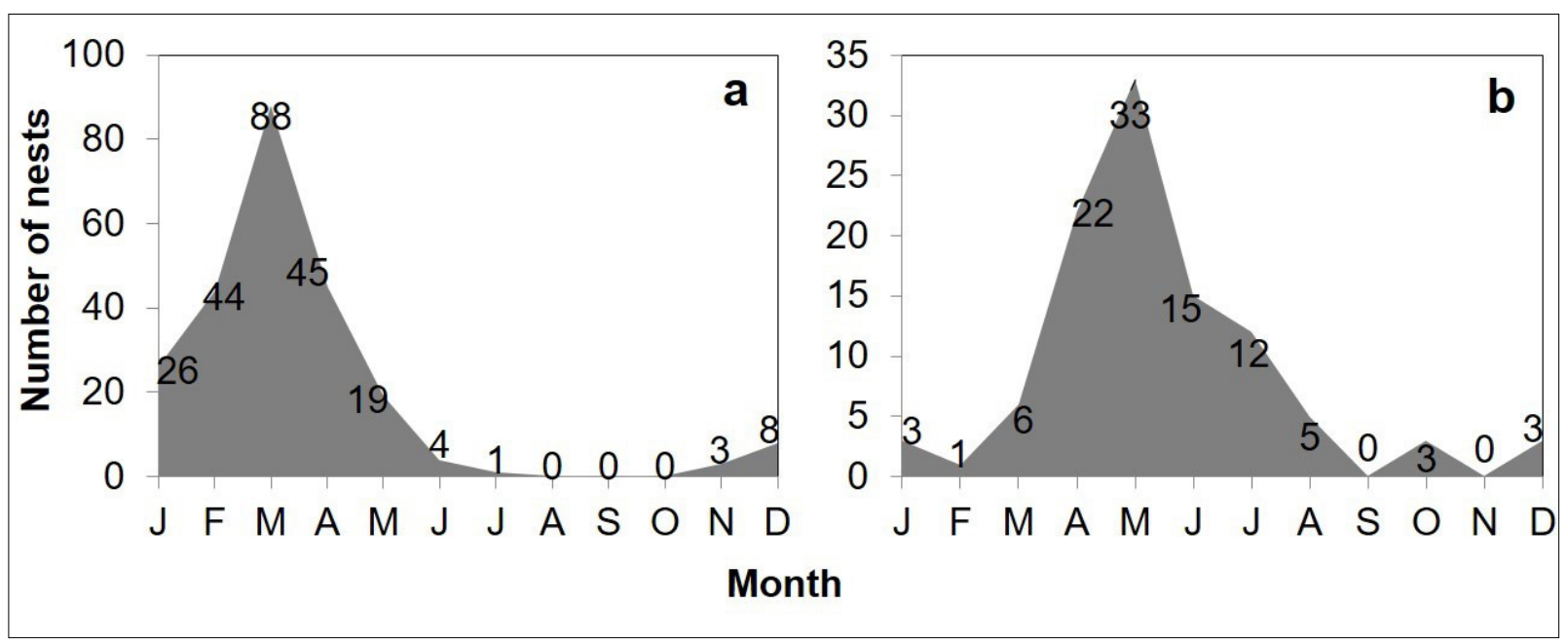

Figure 3. Number of nests of Eretmochelys imbricata (a) and Lepidochelys olivacea (b) recorded by months in the Potiguar Basin, January 2011 December 2019.

Table 2. Hatching success rate and mean incubation time along the nesting season of hawksbill (Eretmochelys imbricata) and olive Ridley (Lepidochelys olivacea) sea turtles in the Potiguar Basin, January 2011 - December 2019.

\begin{tabular}{lccccccc}
\hline \multirow{2}{*}{ Species } & Month & \multicolumn{2}{c}{ Hatching success (\%) } & \multicolumn{3}{c}{ Incubation time (days) } \\
& & Mean & Range & n & Mean & Range & n \\
\hline \multirow{5}{*}{ Eretmochelys imbricata } & December & $67.07 \pm 27.95$ & $17.56-96.11$ & 7 & $55.86 \pm 4.38$ & $50-62$ & 7 \\
& January & $43.78 \pm 35.33$ & $0.00-93.57$ & 19 & $58.94 \pm 2.14$ & $55-64$ & 16 \\
& February & $56.87 \pm 32.59$ & $0.00-100$ & 36 & $57.67 \pm 3.32$ & $48-63$ & 33 \\
& March & $54.07 \pm 33.52$ & $0.00-100$ & 66 & $57.6 \pm 3.33$ & $44-60$ & 65 \\
& April & $48.17 \pm 35.64$ & $0.00-98.41$ & 37 & $57.48 \pm 2.74$ & $52-61$ & 31 \\
& May & $62.22 \pm 32.98$ & $0.00-94.44$ & 11 & $54.17 \pm 7.36$ & $40-61$ & 6 \\
& March & $40.82 \pm 25.49$ & $11.9-60$ & 3 & $59.5 \pm 0.71$ & $59-60$ & 2 \\
& April & $61.39 \pm 30.90$ & $0.00-100$ & 18 & $54.65 \pm 4.91$ & $44-60$ & 17 \\
& May & $61.74 \pm 31.67$ & $10.00-100$ & 33 & $54 \pm 4.06$ & $43-61$ & 32 \\
& June & $79.17 \pm 21.69$ & $30.26-99.2$ & 14 & $56.62 \pm 2.90$ & $53-62$ & 13 \\
& July & $58.81 \pm 33.16$ & $16.13-96.97$ & 11 & $54.22 \pm 3.9$ & $49-60$ & 9 \\
& August & $63.13 \pm 30.57$ & $17.5-94.23$ & 5 & $54.2 \pm 5.4$ & $49-63$ & 5 \\
\hline
\end{tabular}

days, $\mathrm{n}=2$ ) (Table 2). The analysis revealed no statistical difference (Kruskal-Wallis test, E. imbricata $H 5=4.076, P=0.539$; L. olivacea $H 5=6.818, P=0.235$ ) between the monitored months (Table 2). Sand slope was the nest site with higher incubation time for E. imbricata (60 days for each three nests) and vegetation for L. olivacea $(56.67 \pm$ 3.06 days, $\mathrm{n}=3$ ). There was no statistical difference of nest sites for $E$. imbricata (Kruskal-Wallis test, $H 2=0.384, P=0.825$ ), and L. olivacea (Mann-Whitney U test, $U=37.000, N 1=23, N 2=3, P=0.880$ ). All results according to nest sites are shown in Table S1.

The highest incubation time was recorded in nests with $20-29 \mathrm{~cm}$ depth for E. imbricata (60 days for each nine nests) and between 40-49 $\mathrm{cm}$ depth for L. olivacea $(60.5 \pm 0.71$ days, $\mathrm{n}=2)$ (Table S2). There was no correlation between nest depth and incubation time (Spearman rank correlation, E. imbricata $\mathrm{rs}=0.054, N=59, P=0.606$; L. olivacea $\mathrm{rs}=$ $0.001, N=33, P=0.997)$. Nests found between $49-70 \mathrm{~m}$ from the highest tide line presented the highest incubation time for E. imbricata $(59.75$ \pm 0.5 days, $\mathrm{n}=4$; Spearman rank correlation, $\mathrm{rs}=-0.041, N=70, P=$
$0.661)$ and between $26-46 \mathrm{~m}$ for $L$. olivacea $(56.2 \pm 4.15$ days, $\mathrm{n}=5$; Spearman rank correlation, $\mathrm{rs}=-0.119, N=47, P=0.427$ ) (Table S3).

\section{Weather data}

High precipitation and air relative humidity were recorded from January to May, with the highest value in February and March $(2.27 \pm$ $7.13 \mathrm{~mm} ; 72.98 \pm 7.17 \%$, respectively). The warm season was between September and May and the highest temperatures were recorded in December $\left(28.56 \pm 0.72{ }^{\circ} \mathrm{C}\right)$ and January $\left(28.54 \pm 0.87^{\circ} \mathrm{C}\right)$ (Figure 4).

Precipitation between 0 and $22 \mathrm{~mm}$ and humidity higher than $69 \%$ increased hatching success; however, its decrease was recorded over 22 $\mathrm{mm}$ (inflection point) and from $40 \%$ to $69 \%$ for E. imbricata. Regarding air temperature, hatching success increased between $28.5{ }^{\circ} \mathrm{C}$ and 31 ${ }^{\circ} \mathrm{C}$ (Figure $5 \mathrm{a}, \mathrm{b}, \mathrm{c}$ ). For L. olivacea, the highest hatching success rate was recorded about $11 \mathrm{~mm}$ of rainfall and $64 \%$ of $\mathrm{RH}$, with a decrease between $0-11 \mathrm{~mm}$ and at lower humidity (50\%-64\%). Temperatures 


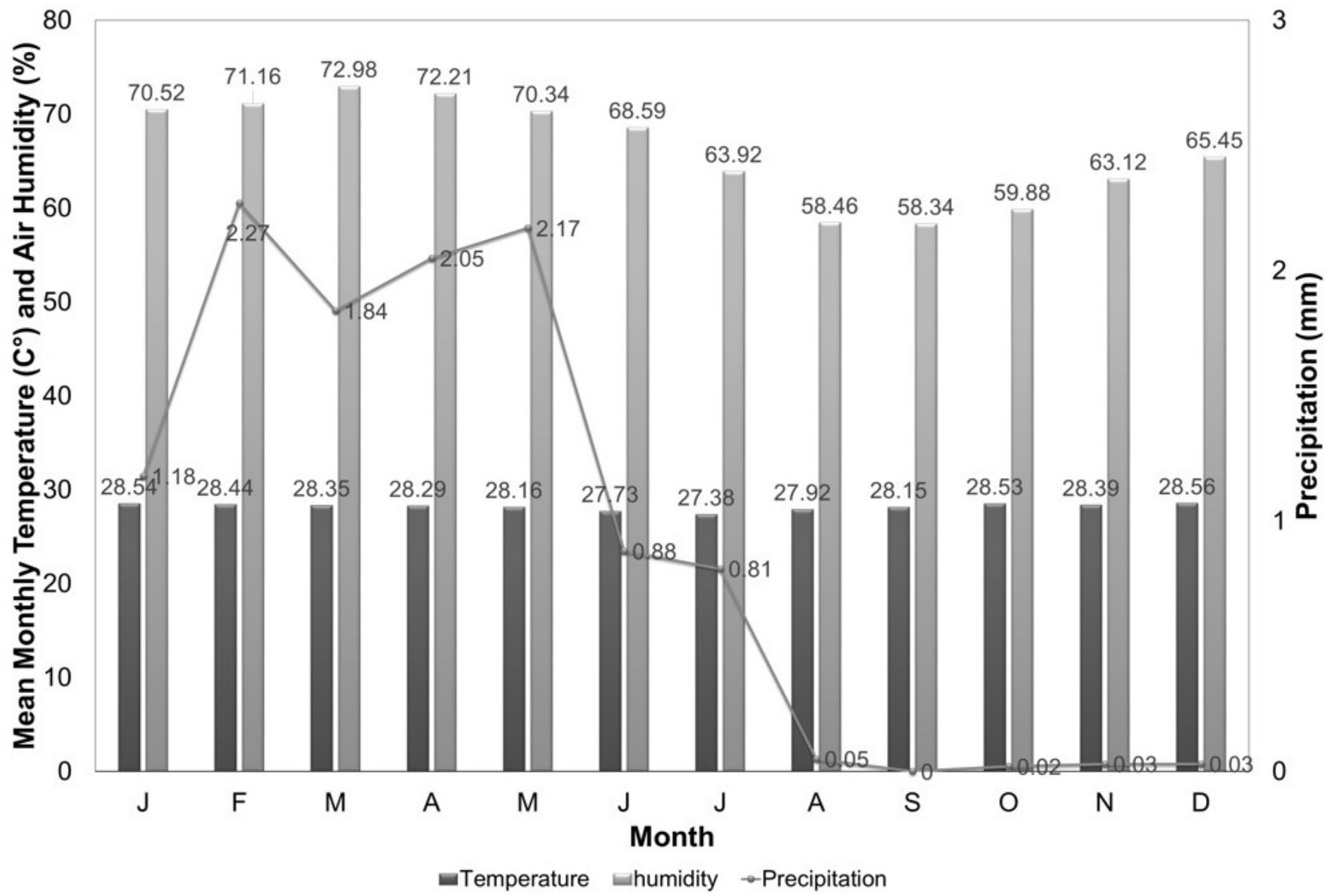

Figure 4. Monthly means of climatic conditions in the Potiguar Basin, January 2011 - December 2019.

Precipitation $(\mathrm{mm})$, air humidity $(\%)$, and air temperature $\left({ }^{\circ} \mathrm{C}\right)$.

between $25^{\circ} \mathrm{C}$ and $28^{\circ} \mathrm{C}$ increased hatching success (with a decrease above $28^{\circ} \mathrm{C}$ ) (Figure $5 \mathrm{~d}, \mathrm{e}, \mathrm{f}$ ).

\section{Threats}

We recorded 16 nests with signs of eggs collection (egg theft). Two nests of olive Ridley and 14 of non-identified species, because the nests were totally empty (Figure 6a). High human predation was recorded during the five first years of our survey $(68.75 \% ; 11 / 16)$ with a decrease in the following years, probably due to the daily monitoring and environmental education carried out by PCCB-UERN. Non-formal environmental education campaigns have been carried out involving people who live in the study site in order to raise public awareness of sustainable interaction between human population and nature, under nature conservation perspective including subjects such as marine ecosystem and anthropogenic interactions.

The field team also found dead or alive hatchlings (Figure 6b), which were disoriented due to artificial lights in the nesting grounds due to the growing coastal development. Live and healthy hatchlings were delivered to the sea. The frequent presence of human on nesting grounds causes other threats, which were noted during monitoring, such as tracks of hatchlings associated to the vehicle tyre tracks on the sand, especially in Galinhos Beach (RN) (Figure 6c) and hatchlings tangled in nets or plastic residues (Figure 6d).

\section{Discussion}

Nests of E. imbricata and L. olivacea were not distributed uniformly along the coastal municipalities monitored and nests were deposited mainly on the beaches of Macau/RN and Guamaré/RN, with greater emphasis on the former. Areas of these municipalities are included in the Ponta do Tubarão State Sustainable Development Reserve (RDSEPT), which covers an area of $12,946.03$ ha, $95 \%$ of its territory belonging to Macau and 5\% to Guamaré. The RDSEPT comprises the estuarine system of the Tubarão River, Ponta do Tubarão, and the sandbank adjacent to the districts of Diogo Lopes and Barreiras, located in Macau (Dias \& Salles 2006). Disposition of these environmental elements makes the coastal environment more protected, therefore we believe that the largest number of nests in this area is due to the absence of artificial lighting, as light pollution affects the spawning activity of marine turtles (Raymond 1984, Witherington 1992, Witherington \& Frazer 2003, Brei et al. 2016, Sforza et al. 2017).

The reproductive season of E. imbricata in the Potiguar Basin was similar to that recorded on the coast of Bahia, Pernambuco, and eastern coast of the state of Rio Grande do Norte (Marcovaldi et al. 2007, Camillo et al. 2009, Moura et al. 2012, Simões et al. 2014). The reproductive season of L. olivacea lasted from March to August, with a peak in May, different from records from the coast of Sergipe and Bahia States (Silva et al. 2007), the region with most nests of this species in 

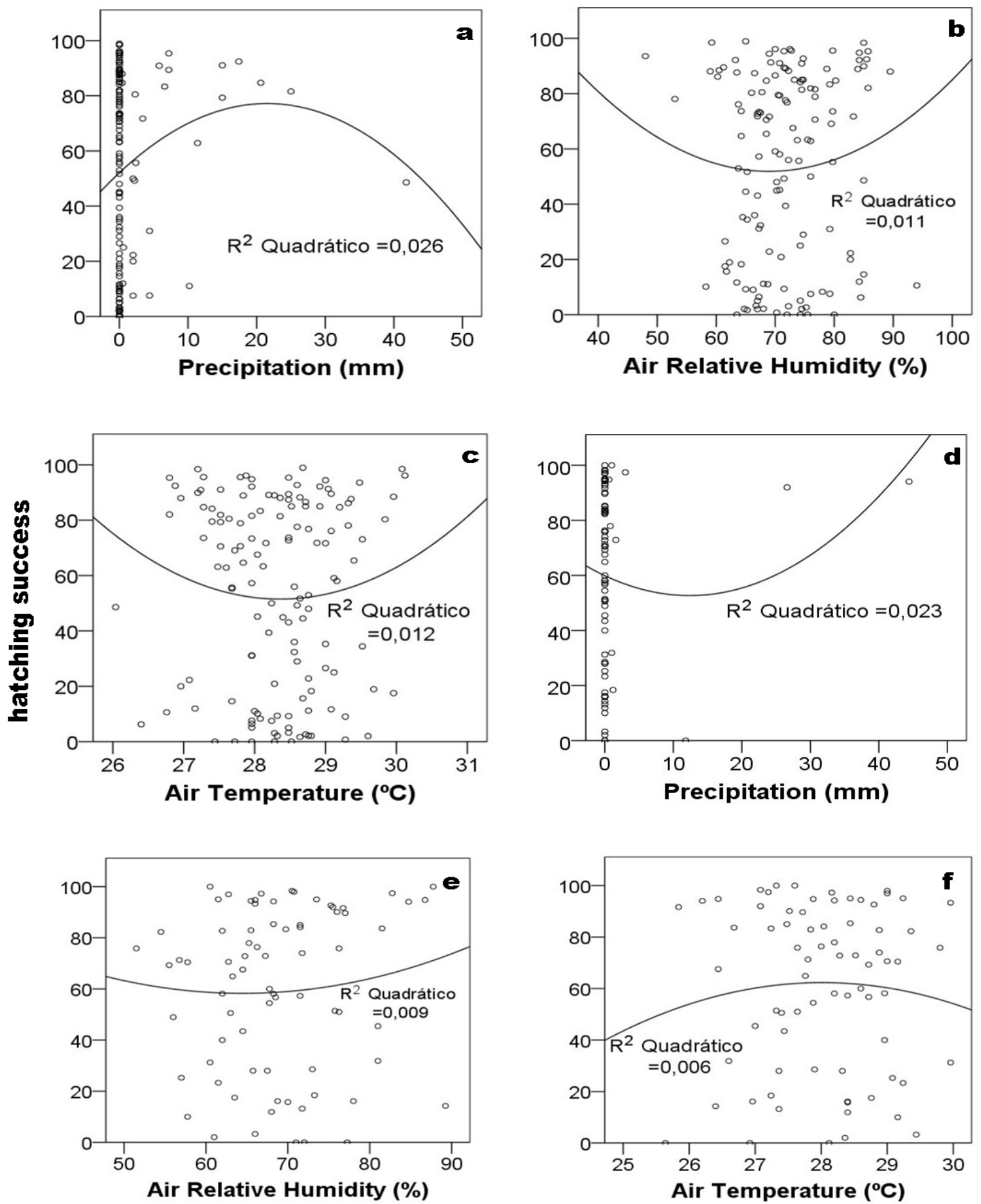

Weather data

Figure 5. Means of precipitation, relative humidity, and air temperature in the Potiguar Basin, in 2011-2019, regarding hatching success of clutches of Eretmochelys imbricata (a, b, c) and Lepidochelys olivacea (d, e, f).

Brazil, where spawning begins in September and ends in March, peaking in December. This difference may be explained by the adaptation of $L$. olivacea to minimize interspecific competition in the same spawning area of E. imbricata by means of temporal displacement during the nesting season. A similar result was observed for the species $E$. imbricata and C. caretta on the southern coast of Bahia (Camillo et al. 2009).

Our results show that the hawksbill turtles that spawned in the Potiguar Basin had lower clutch size compared to results in previous 


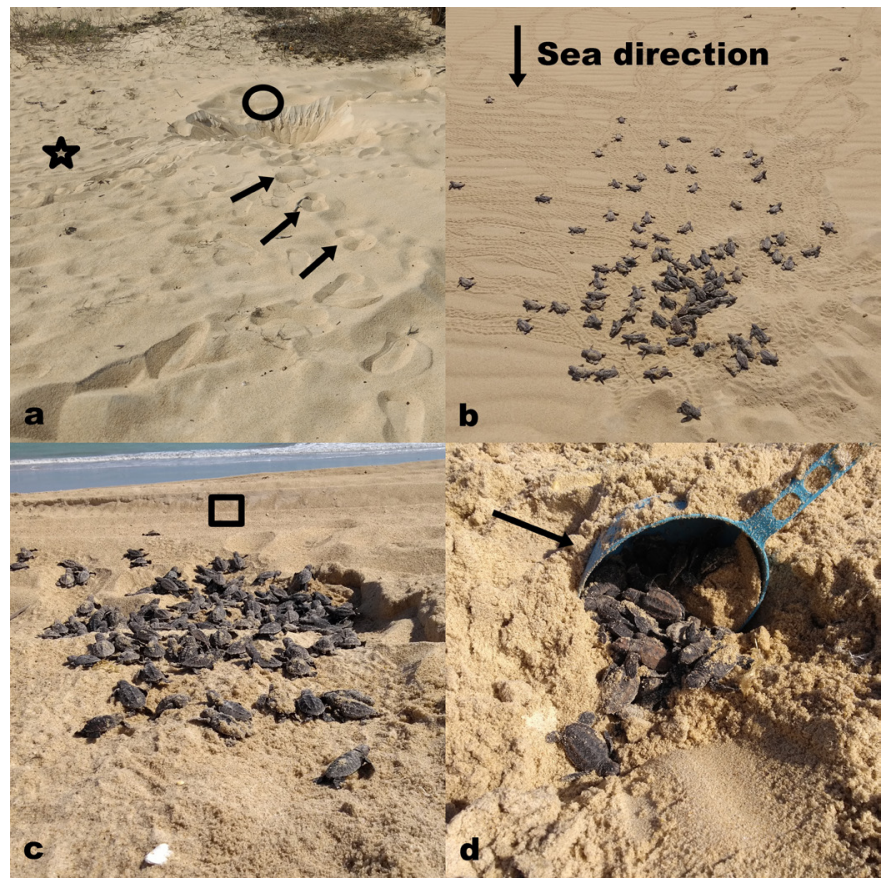

Figure 6. Threats to sea turtle nests and hatchlings in the Potiguar Basin, Brazil. (a) Nest registered on Aug 16, 2017, at Galinhos Beach, municipality of Galinhos/ $\mathrm{RN}$, with evidence of human predation: human footprints (arrows), sea turtle trail (star), and nest excavated for theft the eggs (circle), with only one egg left in place. (b) Disoriented hatchlings and in a direction contrary to the sea, registered on Feb 4, 2019, at Catavento Beach, municipality of Galinhos/RN. (c) Vehicle trail (square) as an obstacle/threat to hatchlings, registered on Feb 09, 2019, at Fazenda Beach, municipality of Galinhos/RN. (d) Hatchlings trapped in a domestic sieve registered on Dec 1, 2017, at Dunas Beach, municipality of Galinhos/RN.

studies on the eastern coast of RN and in Pernambuco (Santos 2008, Simões et al. 2014). On the other hand, hawksbill turtles showed higher clutch size compared to females that spawned on the southern coast of Bahia (Camillo et al. 2009). Nests of E. imbricata in the Potiguar Basin have more unhatched eggs and dead hatchlings and fewer live hatchlings when compared to nests monitored on the coast of Pernambuco (Simões et al. 2014, Moura et al. 2012). The incubation time was shorter than that found on the eastern coast of RN and southern Bahia (Santos 2008, Camillo et al. 2009).

Sea turtles of species L. olivacea that spawned in the Potiguar Basin had lower clutch size when compared to females that spawned in the states of Sergipe and Bahia in Brazil, in Playa Grande in Costa Rica, and in Cape Van Diemen in Australia (Marcovaldi \& Laurant 1996, Silva et al. 2007, Whiting et al. 2007, Dornfeld et al. 2014). This species has two types of reproductive behavior. One is the independent (solitary) behavior and the other is called arribada, in which females behave in a synchronized and massive way (Dornfeld et al. 2014). Most studies have focused on nesting beaches with arribada behavior, even though the solitary behavior is the most common. Few studies evaluated the nesting of L. olivacea in Brazil, where independent reproductive behavior occurs, whose importance is evidenced for species conservation (Dornfeld et al. 2014).

The average hatching success rate recorded in the Potiguar Basin for E. imbricata and L. olivacea was lower than that obtained elsewhere in Brazil and in the world (Silva et al. 2007, Whiting et al. 2007, Santos 2008, Camillo et al. 2009, Moura et al. 2012, Dornfeld et al. 2014), indicating the vulnerability of these species in our study site. This may be related to environmental characteristics during the incubation period, which mainly influence temperature and humidity inside the nest (Ackerman 1997, Ferreira Jr 2009). Wave disturbances in the Campo dos Alísios (Pertubações Ondulatórias no Campo dos Alísios - POA) are important in the total rainfall of RN. The POA waves primarily affect the eastern coast of the Brazilian northeast. Therefore, the northern coast rarely has rain associated with this phenomenon and when precipitation occurs, it is much lower than that on the eastern coast, as the POA hit the eastern coast first, lose humidity, and only after, they reach the northern coast (Diniz \& Pereira 2015). Sea and land breezes play an important role in the increase of total rainfall on the eastern coast of RN and have great importance to inhibit rainfall on the northern coast. On the northern coast, land breeze comes from the south, southeast, or southwest, and is responsible to push rain clouds off the coast, causing rains to fall on the Atlantic; thus, this portion of the RN coast is the driest stretch of the entire Brazilian coast (Diniz \& Pereira 2015). Low rainfall in the region contributes to lower humidity and higher temperature, which can affect the hatching success rate of sea turtle nests.

The hawksbills monitored had larger clutch size, incubation time, number of unhatched eggs, and dead hatchlings compared to olive Ridley sea turtles. However, variation in clutch size, clutch frequency, breeding frequency, and remigration intervals have been observed in individuals of the same species, as recorded for loggerhead sea turtles that lay their eggs on the same beach, but use different foraging grounds with varied food availability (Hatase et al. 2013). Thus, differences in clutch size between the species of sea turtles could be explained by genetic characteristics of females and variation of their habitats (Tiwari \& Bjorndal 2000, Gillis et al. 2008, Grayson et al. 2011). In addition, the clutch size is strongly associated with the body size of females, which varies between species and between populations (Van Buskirk $\&$ Crowder 1994, Broderick et al. 2003). Our results are in line with this knowledge, considering that hawksbills turtles have a larger body size when compared to the olive Ridley, as reported in previous studies (Marcovaldi et al. 1999, Silva et al. 2007).

Nest site types, depth, and distance from the highest tide line of hawksbill sea turtles nests did not differ statistically, although the nests on sand slope, 30-39 $\mathrm{cm}$ deep and 49-70 $\mathrm{m}$ from the highest tide line presented a higher hatching success rate. Other studies have also shown that nest depth of hawksbill turtles and green turtles does not influence the hatching success of these species (Zárate et al. 2013, Defever 2019). On the other hand, some studies reported an influence on hatchling and hatchery survival due to the relationship between nest temperature and egg chamber depth (Sarahaizad \& Shahrul-Anuar 2014, Hill et al. 2015, Tomillo et al. 2017). We recorded hawksbill turtles spawning at a greater distance from the highest tide line $(68 \mathrm{~m})$ than on the eastern coast of RN (31 m; Santos et al. 2016) and in Barbados (22.5 m; Horrocks \& Scott 1991). We found more nests of E. imbricata deposited in areas with open sand, corroborating previous studies on the eastern coast of RN (Santos et al. 2016); however, differing from the results obtained in the Caribbean, which showed more nests in an area with vegetation cover (Kamel \& Mrosovsky 2006a, b). Nevertheless, open sand nests may be more exposed to the sun, leading to decreased hatching success. We recorded longer incubation periods in the nests located in the sand slope, which favors the development of embryos, despite the action of high tides (Marcovaldi et al. 2014). 
Olive Ridley sea turtles nests on vegetation, with 30-39 cm deep and found between 5-25 $\mathrm{m}$ from the highest tide line, presented higher hatching success rate. However, we recorded a larger number of nests in open sand at 30-39 cm deep, similar to results reported in another study in Costa Rica (Drake et al. 2003). The spawning site has a major influence on the hatching success of turtles (Mrosovsky 1980). Comparisons between leatherback, green, and olive Ridley sea turtles revealed greater thermal stability for deeper leatherback nests (Tomillo et al. 2017). In our study, we observed that $L$. olivacea nests at 5-25 $\mathrm{m}$ from the highest tide line showed a tendency of greater hatching success, similar to observations of López-Castro et al. (2004), whose hatching success was greater for nests deposited between 10-30 $\mathrm{m}$ far from the high tide line.

Nests of E. imbricata showed greater hatching success and shorter incubation time at the beginning of the reproductive season (December), when precipitation is lower and humidity and air temperature is higher. On the other hand, nests of L. olivacea with the greatest hatching success were recorded in June, the end of the reproductive season and the period with the highest precipitation and humidity and lowest air temperature. Reproductive success and incubation duration for species that bury eggs, such as sea turtles, may vary depending on variations in ambient temperature, rainfall, relative humidity, sand particle size, and $\mathrm{CO}_{2}$ and $\mathrm{O}_{2}$ concentrations that act directly on the development of neonates (Webb \& Cooper-Preston 1989, Ackerman 1997, Ferreira Jr et al. 2003, Ferreira Jr 2009, Tomillo et al. 2012).

Regarding the climatic conditions, we recorded an increase in the hatching success between $0 \mathrm{~mm}$ and $22 \mathrm{~mm}$ of precipitation for hawksbill sea turtles, while L. olivacea showed a higher hatching success from $11 \mathrm{~mm}$ onward. Our results corroborate with a previous study, whose results demonstrated that low rainfall was harmful for egg incubation and for hatchlings emerging from leatherback sea turtles nests (Tomillo et al. 2012). However, studies carried out in a hatchery in Playa Grande, Costa Rica, found a more prolonged effect of shading than water in reducing the temperature of $D$. coriacea nests (Hill et al. 2015). The hatching success was greater under relative humidity equals to or higher than $69 \%$ for E. imbricata and from $64 \%$ onward for $L$. olivacea. A similar result was obtained for nests of $C$. caretta in Florida (USA) (Lolavar \& Wyneken 2020). We recorded an increase in hatching success from the inflection point of $28.5{ }^{\circ} \mathrm{C}$ to $31{ }^{\circ} \mathrm{C}$ for E. imbricata and between $25^{\circ} \mathrm{C}$ and $28^{\circ} \mathrm{C}$ for L. olivacea. However, from $28^{\circ} \mathrm{C}$ onward, there was a decrease in the hatching success of eggs of Ridley sea turtles, differing from studies conducted in Costa Rica, which registered reductions from $31{ }^{\circ} \mathrm{C}$ and $32{ }^{\circ} \mathrm{C}$ onward (Dornfeld et al. 2014, Tomillo et al. 2017). Environment and nest temperatures are closely correlated (Márquez 1990); therefore, population resilience to climate warming may depend on the balance between temperatures to generate offspring also the temperature that reduces their survival.

Sea turtles, their nests, and their offspring are often exposed to different threats, such as urban development on the coast (Kamrowski et al. 2014, Lopez et al. 2015), pollution, (Farias et al. 2019, Soares et al. 2020), climate change (Tomillo et al. 2015, Reneker \& Kamel 2016), and interaction with fishing (Castilhos et al. 2011, Guebert et al. 2013). Theft of eggs is an old threat and it still occurs today, as observed in our study site. The coastal development did not aggravate the old threats (e.g. egg poaching), but it has triggered new problems (Lopez et al. 2015). Currently, light pollution is one of the greatest threats to the survival of sea turtle hatchlings, especially in more densely populated areas. Artificial lights can disrupt the behavior of turtles to find the direction toward the sea, making them more susceptible to mortality due to exhaustion, dehydration, and predation (Kamrowski et al. 2014, Lopez et al. 2015). As stated by Santos et al. (2011), the vehicles can compact the sand where sea turtles laid their eggs hampering hatchlings out of the nests, and the vehicle trails make difficult the movement of the hatchlings to the sea become them more vulnerable to predation. Plastic waste on the beach and in the sea also interfere the hatchlings survival once they can trapped in this kind of residue, including fragments of fishing nets (Santos et al. 2011). In our study, many hatchlings were found under these conditions. To a lesser extent, we found offspring tracks associated to vehicle tracks on the beaches, as well as newborns entangled in fragments of fishing nets or plastic waste.

Intensive development in the coastal zones poses a risk to sea turtle populations when physical characteristics of the sea turtle spawning sites are modified by sand removal and beach nourishment. This affects egg chambers, hinders water absorption and the movement of newborns in the nests, changes the incubation temperature and gas exchange rates, interferes with sex ratio, and compromises the survival of eggs and hatchlings (Santos et al. 2011, Lopez et al. 2015). Such changes can turn the beach unfeasible for egg laying by females reducing the number of nesting sites, as mentioned by the National Action Plan for Sea Turtles Conservation (Plano de Ação Nacional para Conservação das Tartarugas Marinhas), (Santos et al. 2011).

Non-formal environmental education campaigns carried out by PCCB-UERN during the study period resulted in a decrease of egg removal by human after five years of our survey. According to Bizzo (2009), daily knowledge is considered during the teaching-learning process once people learn about this knowledge since they are very young. Therefore, activities involving all people (local residents, tourists and entrepreneurs) with different ages became necessary, especially in the areas of high relevance.

Our study revealed spawning of E. imbricata and L. olivacea in the Potiguar Basin and the municipalities of Macau/RN and Guamaré/ RN were the prevailing breeding areas for these species. Successful incubation of sea turtles is important for the survival of these vulnerable species; thus, evaluation of factors related to the hatchlings survival in the study site are extremely important. Theft of eggs, light pollution, vehicle traffic, and plastic waste on the beaches are anthropic activities that influence the survival of hatchlings in the spawning sites. In addition, the distance traveled by the turtles for spawning is also critical information for the adoption of measures to protect the nesting sites. Therefore, protection of nesting sites increases genetic variability of populations and contributes to the conservation of sea turtles. Measures must be adopted to protect nesting habitats in the Potiguar Basin through effective coastal zone management plans that limit the use of artificial lights, buildings, and intense human presence in areas that overlap beaches with spawning sites of sea turtles in the basin studied. In addition, we suggest (1) a continuous environmental education program to raise public awareness (local residents, tourists and entrepreneurs) focused on beach conservation to ensure the nesting activities of sea turtles, and (2) a continuous monitoring program for the protection of females and hatchlings in order to reduce impacts on populations of hawksbill and olive Ridley sea turtles. 


\section{Supplementary material}

The following online material is available for this article:

Table S1 - Hatching success rate and mean incubation time of hawksbill (Eretmochelys imbricata) and olive Ridley (Lepidochelys olivacea) sea turtles according to nest sites in the Potiguar Basin, January 2018 - December 2019.

Table S2 - Hatching success rate and mean incubation time according to the depth of nests of hawksbill (Eretmochelys imbricata) and olive Ridley (Lepidochelys olivacea) sea turtles in the Potiguar Basin, January 2016 - December 2019.

Table S3 - Hatching success rate and mean incubation time of nests of hawksbill (Eretmochelys imbricata) and olive Ridley (Lepidochelys olivacea) sea turtles according to the distance from the highest tide line in the Potiguar Basin, January 2015 - December 2019.

\section{Acknowledgements}

We thank the staff of Projeto Cetáceos da Costa Branca, Universidade do Estado do Rio Grande do Norte (PCCB-UERN); Giovanna Almeida Santoro for her assistance with the map edition; the reviewers for the constructive comments; and Coordenação de Aperfeiçoamento de Pessoal de Nível Superior (CAPES; process number 88882.376106/2019-01). This study was carried out through the Licensing Environmental Conditioner conducted by the Brazilian Institute of Environment and Renewable Natural Resources (IBAMA) - Ministry of the Environment for Petrobras Oil and Gas Exploration and Production activities in the Potiguar Basin (Authorization: ABIO 269/2013; Process: 02022.000050 / 2013). It was also authorized by Chico Mendes Institute for Biodiversity Conservation (ICMBio) Ministry of the Environment through the Biodiversity Information and Authorization System (SISBIO 13694-6). Silmara Rossi is a recipient of postdoctoral fellowship by the Postdoctoral National Program (CAPES; process number 88882.306020/2018-01), Structural and Functional Biology Postgraduate Program - Federal University of Rio Grande do Norte.

\section{Author Contributions}

Aline da Costa Bomfim: substantial contribution in the concept and design of the study; contribution to data collection; contribution to data analysis and interpretation; contribution to manuscript preparation; contribution to critical revision, adding intellectual content.

Daniel Solon Dias de Farias: substantial contribution in the concept and design of the study; contribution to data collection; contribution to data analysis and interpretation; contribution to manuscript preparation.

Flávio José de Lima Silva: substantial contribution in the concept and design of the study; contribution to data collection; contribution to data analysis and interpretation; contribution to manuscript preparation.

Silmara Rossi: contribution to data analysis and interpretation; contribution to manuscript preparation; contribution to critical revision, adding intellectual content.

Simone Almeida Gavilan: substantial contribution in the concept and design of the study; contribution to data collection; contribution to data analysis and interpretation; contribution to manuscript preparation.

Vinícius Gabriel da Silva Santana: contribution to data analysis and interpretation; contribution to manuscript preparation.
Cibele Soares Pontes: contribution to data analysis and interpretation; contribution to manuscript preparation; contribution to critical revision, adding intellectual content.

\section{Conflicts of Interest}

The authors declare no conflict of interest related to the publication of this manuscript.

\section{References}

ABREU-GROBOIS, A. \& PLOTKIN, P. 2008. IUCN SSC Marine Turtle Specialist Group. Lepidochelys olivacea. The IUCN Red List of Threatened Species 2008: e.T11534A3292503. https://www.iucnredlist. org/species/11534/3292503 (last access in 31/05/2020).

ACKERMAN, R.A. 1997. The Nest Environment and the Embryonic Development of Sea Turtles. In The Biology of Sea Turtles (P.L. Lutz \& J.A. Musick, eds). CRC Press, Boca Raton, p. 83-107.

BELLINI, C. \& SANCHES, T.M. 1996. Reproduction and feeding of marine turtles in the Fernando de Noronha Archipelago, Brazil. M T N. 74: 12-13.

BELLINI, C., SANTOS, A.J.B., GROSSMAN, A., MARCOVALDI, M.A. \& BARATA, P.C.R. 2013. Green turtle (Chelonia mydas) nesting on Atol das Rocas, north-eastern Brazil, 1990-2008. J. Mar. Biol. Assoc. UK. 93 (4): 1117-1132.

BIZZO, N. 2009. Conhecimento: Científico e Cotidiano. In: Ciências: fácil ou difícil? São Paulo, Biruta.

BREI, M., PÉREZ-BARAHONA, A. \& STROBL, E. 2016. Environmental pollution and biodiversity: light pollution and sea turtles in the caribbean. J. Environ. Econ. Manag. 77: 95-116.

BRODERICK, A.C., GLEN, F., GODLEY, B.J. \& HAYS, G.C. 2003. Variation in reproductive output of marine turtles. J. Exp. Mar. Biol. Ecol. 288: 95-109.

CAMILLO, C.S., ROMERO, R.M., LEONE, L.G., BATISTA, R.L.G., VELOZO, R.S. \& NOGUEIRA-FILHO, S.L.G. 2009. Características da reprodução de tartarugas marinhas (Testudines, Cheloniidae) no litoral sul da Bahia, Brasil. Biota Neotropica. 9 (2): 131-137. http://www.biotaneotropica.org. br/v9n2/en/abstract?article+bn02209022009 (last access on 10/09/2020)

CARVALHO, R.H., MAMEDE, N., BASTOS, R.R. \& SOUSA, B.M. 2016. Attitudes towards conservation and fishing interaction with sea turtles in the southeast coast of Brazil. Ocean Coast. Manage. 127: 55-62.

CASALE, P. \& TUCKER, A.D. 2017. Caretta caretta (amended version of 2015 assessment). The IUCN Red List of Threatened Species 2017: e.T3897A119333622. https://dx.doi.org/10.2305/IUCN.UK.2017-2.RLTS T3897A119333622.en (last access in 31/05/2020).

CASTilhos, J.C., COElHO, C.A., ARGOlO, J.F., SANTOS, E.A.P., MARCOVALDI, M.A., SANTOS, A.S. \& LOPEZ, M. 2011. Avaliação do estado de conservação da tartaruga marinha Lepidochelys olivacea (Eschscholtz, 1829) no Brasil. BioBrasil. https://www2.icmbio.gov.br/ revistaeletronica/index.php/BioBR/article/viewFile/90/75 (last access in 18/03/2020).

CHATTING, M., SMYTH, D., AL-MASLAMANI, I., OBBARD, J., ALANSI, M., HAMZA, S., AL-MOHANADY, S.F., AL-KUWARI, A.J. \& MARSHALL, C.D. 2018. Nesting ecology of hawksbill turtles, Eretmochelys imbricata, in an extreme environmental setting. PLoS One. 13 (9): 01-10.

COSTA, S.A.G.L., SILVA, F.J.L., FARIAS, D.S.D., FRAGOSO, A.B.L., COSTA, T.E.B., ALENCAR, A.E.B. 2016. Pesquisa e Conservação de Tartarugas Marinhas na Bacia Potiguar, Rio Grande do Norte, Nordeste do Brasil. In Conservação de Tartarugas Marinhas no Nordeste do Brasil: Pesquisas, Desafios e Perspectivas (J.M.S. Correia, E.M. Santos, G.J.B. Moura, orgs). EDUFRPE, Recife, p. 257.

DEFEVER, J. 2019. The Effect of Biotic and Abiotic Factors on the Hatching Success of the Hawksbill Sea Turtle (Eretmochelys imbricata) on Mahé Island, Seychelles. Dissertation, Ghent University. 
DIAS, T.L.P. \& SALLES, R. 2006. Diagnóstico da pesca artesanal e proposta de plano de ordenamento da pesca na reserva de desenvolvimento sustentável Ponta do Tubarão (Macau-Guamaré/RN). Relatório técnico IDEMA, p. 106.

DINIZ, M.T.M. \& PEREIRA, V.H.C. 2015. Climatologia do Estado do Rio Grande do Norte, Brasil: Sistema Atmosféricos Atuantes e Mapeamento de Tipos de Clima. Bol. Goia. Geogr. 35 (3): 488-506.

DORNFELD, T.C., ROBINSON, N.J., TOMILLO, P.S. \& PALADINO, F.V. 2014. Ecology of solitary nesting olive ridley sea turtles at Playa Grande, Costa Rica. Mar. Biol. 162: 123-139.

DRAKE, D.L., BEHM, J.E., HAGERTY, M.A., MAYOR, P.A., GOLDENBERG, S.J. \& SPOTILA, J.R. 2003. Marine Turtle Nesting Activity at Playa Naranjo, Santa Rosa National Park, Costa Rica, for the 1998-1999 Season. Chelonian Conserv. Bi. 4 (3): 675-678.

FARIAS, D.S.D., ALENCAR, A.E.B., BOMFIM, A.C., FRAGOSO, A.B.L., ROSSI, S., MOURA, G.J.B., GAVILAN, S.A. \& SILVA, F.J.L. 2019. Marine Turtles Stranded in Northeastern Brazil: Composition, Spatio-Temporal Distribuition, and Anthropogenic Interaction. Chelonian Conserv. Bi. 18 (1): 105-111.

FERNANDES, M.L.B., SILVA, L.C.C., MOURA, G.J.B. 2016. Influência dos Impactos Ambientais na Escolha da Praia de Desova da Espécie Eretmochelys imbricata. Biota Amazônia. 6 (4): 44-48.

FERREIRA-JÚNIOR, P.D., CASTRO, P.T.A., ADDAD, J.E. \& LORENZO, M. 2003. Aspectos fisiográficos das áreas de nidificação da tartaruga marinha Caretta caretta na praia da Guanabara, Anchieta, Espírito Santo, Arujá, SP. Anais do Instituto Pau Brasil de História Natural. 7: 25-40.

FERREIRA-JÚNIOR, P.D. 2009. Efeitos de Fatores Ambientais na Reprodução de Tartarugas. Acta Amazon. 39 (2): 319-334.

GILLIS, E.A., GREEN, D.J., MIDDLETON, H.A. \& MORRISSEY, C.A. 2008. Life history correlates of alternative migratory strategies in american dippers. Ecology. 89 (6): 1687-1695.

GRAYSON, K.L., BAILEY, L.L., WILBUR, H.M. 2011. Life history benefits of residency in a partially migrating pond-breeding amphibian. Ecology. 92 (6): 1236-1246.

GROSSMAN, A., BELLINI, C. \& MARCOVALDI, M.A. 2003. Reproductive biology of the green turtle at the Biological Reserve of Atol das Rocas off northeast Brazil. In Proceedings of the 22nd Annual Symposium on Sea Turtle Biology and Conservation (J.A. Seminoff, comp.). NOAA Tech. Memo. NMFS-SEFSC-503: 136

GUEBERT, F.M., BARLETTA, M. \& COSTA, M.F. 2013. Threats to sea turtle populations in the Western Atlantic: poaching and mortality in small-scale fishery gears. J. Coastal Res. 65: 42-47.

HATASE, H., OMUTA, K. \& TSUKAMOTO, K. 2013. A mechanism that maintains alternative life histories in a loggerhead sea turtle population. Ecology. 94 (11): 83-94.

HILL, J.E., PALADINO, F.V., SPOTILA, J.R. \& TOMILLO, P.S. 2015. Shading and Watering as a Tool to Mitigate the Impacts of Climate Change in Sea Turtle Nests. PLoS One. 10 (6): 1-14.

HORROCKS, J.A. \& SCOTT, N.M.C.A. 1991. Nest site location and nest success in the hawksbill turtle Eretmochelys imbricata in Barbados, West Indies. Mar. Ecol. Prog. Ser. 69: 1-8.

INSTITUTO NACIONAL DE METEOROLOGIA (INMET). Banco de Dados Metereológicos para Ensino e Pesquisa. http://www.inmet.gov.br/portal/ index.php? $r=b d m e p / b d m e p$ (last access in 13/02/2020).

IUCN (2017) IUCN Red List of Threatened Species. Version 2017.2. http:// www.iucnredlist.org (last access in 20/01/2020).

JIMENEZ, J.A., MAIA, L.P., SERRA, J. \& MORAIS, J. 1999. Aeolian dune migration along the Ceara coast, north-eastern Brazil. Sedimentology. 46 (4): 689-701.

KAMEL, S.J. \& MROSOVSKY, N. 2006a. Deforestation: risk of sex ratio distortion in hawksbill sea turtles. Ecol. Appl. 16 (3): 923-931.

KAMEL, S.J. \& MROSOVSKY, N. 2006b. Inter-seasonal maintenance of individual nest site preferences in hawksbill sea turtles. Ecology. 87 (11): 2947-2952.

KAMROWSKI, R.L., LIMPUS, C., JONES, R., ANDERSON, S. \& HAMANN, M. 2014. Temporal changes in artificial light exposure of marine turtle nesting areas. Glob. Change Biol. 20 (8): 2437-2449.
LOLAVAR, A. \& WYNEKEN, J. 2020. The Impact of Sand Moisture on the Temperature-Sex Ratio Responses of Developing Loggerhead (Caretta caretta) Sea Turtles. Zoology. 138: 1-28.

LÓPEZ-CASTRO, M.C., CARMONA, R. \& NICHOLS, W.J. 2004. Nesting Characteristics of the Olive Ridley Turtle (Lepidochelys olivacea) in Cabo Pulmo, Southern Baja California. Mar. Biol. 145 (4): 811-820.

LOPEZ, G.G., SALIÉS, E.C., LARA, P.H., TOGNIN, F., MARCOVALDI, M.A. \& SERAFINI, T.Z. 2015. Coastal Development at Sea Turtles Nesting Ground: Efforts to Establish a Tool for Supporting Conservation and Coastal Management in Northeastern Brazil. Ocean Coast. Manage. 116: 270-276.

MARCOVALDI, M.A. \& LAURENT, A. 1996. A Six Season of Marine Turtle Nesting at Praia do Forte, Bahia, Brazil, with Implications for Conservation and Management. Chelonian Conserv. Bi. 2 (1): 55-59.

MARCOVALDI, M.A., VIEITAS, C.F. \& GODFREY, M.H. 1999. Nesting and conservation management of hawksbill turtles (Eretmochelys imbricata) in northern Bahia, Brazil. Chelonian Conserv. Bi. 3: 301-307.

MARCOVALDI, M.A., LOPEZ, G.G., SOARES, L.S., SANTOS, A.J.B., BELLINI, C., BARATA, P.C.R. 2007. Fifteen years of Hawksbill sea turtle (Eretmochelys imbricata) Nesting in Northern Brazil. Chelonian Conserv. Bi. 6 (2): 223-228.

MARCOVALDI, M.A., LOPEZ, G.G., SOARES, L.S., SANTOS, A.J.B., BELLINI, C., SANTOS,A.S. \& LOPEZ,M. 2011. Avaliação do Estado de Conservação da Tartaruga Marinha Eretmochelys imbricata (Linnaeus, 1766) no Brasil. BioBrasil. 1: 20-27.

MARCOVALDI, M.A.G., SANTOS, A.J.B., SANTOS, A.S., SOARES, L.S., LOPEZ, G.G., GODFREY, M.H., LÓPEZ-MENDILAHARSU, M. \& FUENTES, M.M.P.B. 2014. Spatio-temporal variation in the incubation duration and sex ratio of hawksbill hatchlings: implication for future management. J. Therm. Biol. 44: 70-77.

MÁRQUEZ, M.R. 1990. FAO species catalogue. Sea Turtles of the World. An Annotated and Illustrated Catalogue of Sea Turtle Species Known to Date. FAO Fisheries Synopsis. 11 (125): 1-81.

MILLER, J.D. 1999. Determining Clutch Size and Hatching Success. In Research and Management Techniques for the Conservation of Sea Turtles (K.L. Eckert, K.A. Bjorndal, F.A. Abreu-Grobois, M. Donnelly, eds). Prepared by IUCN/SSC Marine Turtle Specialist Group, p. 124-129.

MOREIRA, L.M.P., BAPTISTOTTE, C., SCALFONI, J., THOMÉ, J.C. \& ALMEIDA, A.P.L.S. 1995. Occurrence of Chelonia mydas on the island of Trindade, Brazil. M T N. 70: 2.

MORTIMER, J.A. \& DONNELLY, M. 2008. IUCN SSC Marine Turtle Specialist Group. Eretmochelys imbricata. The IUCN Red List of Threatened Species 2008:e.T8005A12881238. https://dx.doi.org/10.2305/IUCN.UK.2008. RLTS.T8005A12881238.en (last access in 31/05/2020).

MOURA, C.C.M., GUIMARÃES, E.S., MOURA, G.J.B., AMARAL, G.J.A. \& SILVA, A.C. 2012. Distribuição espaço-temporal e sucesso reprodutivo de Eretmochelys imbricata nas praias do Ipojuca, Pernambuco, Brasil. Iheringia. 102 (3): 254-260.

MROSOVSKY, N. 1980. Thermal biology of sea turtle. Am. Zool. 20 (3): 531-547.

PRITCHARD, P.C.H. \& MORTIMER, J.A. 2000. Taxonomía, Morfología Externa e Identificación de las Especies. In Técnicas de Investigación y Manejo para la Conservación de las Tortugas Marinas (K.L. Eckert, K.A. Bjorndal, F.A. Abreu-Grobois, M. Donnelly, eds). Grupo Especialista en Tortugas Marinas UICN/CSE Publicación, p. 23-44.

RAYMOND, P. 1984. Sea turtle hatchling disorientation and articial beachfront lighting. Center for Environmental Education, Washington, DC, USA.

RENEKER, J.L. \& KAMEL, S.J. 2016. Climate Change Increases the Production of Female Hatchlings at a Northern Sea Turtle Rookery. Ecology. 97: 1-25.

RICHARDSON, J.I., BELL, R. \& RICHARDSON, T.H. 1999. Population Ecology and Demographic Implications Drawn From an 11-Year Study of Nesting Hawksbill Turtles, Eretmochelys imbricata, at Jumby Bay, Long Island, Antigua, West Indies. Chelonian Conserv. Bi. 3 (2): 244-250. 
SANTANA, W.M., MAGALHÃES NETO, M.O., SANTANA, E.M., COSTA, A.L., LOPES, S.B., SILVA, R.N. \& NASCIMENTO, M.N.P. 2016. Pesquisa e Conservação de Tartarugas Marinhas no Estado do Piauí, Nordeste do Brasil. In Conservação de Tartarugas Marinhas no Nordeste do Brasil: Pesquisas, Desafios e Perspectivas (J.M.S. Correia, E.M. Santos, G.J.B. Moura, orgs). EDUFRPE, Recife, p. 53.

SANTOS, A.J.B. 2008. Biologia reprodutiva de Eretmochelys imbricata (Testudines, Cheloniidae) no litoral sul do Rio Grande do Norte, Brasil. Dissertação, Universidade Federal do Rio Grande do Norte.

SANTOS, A.S., ALMEIDA, A.P., SANTOS, A.J.B. ET AL (2011) Plano de Ação Nacional para a Conservação das Tartarugas Marinhas (M.A.A.G. Marcovaldi, A.S. Santos, G. Sales, orgs) - Brasília: Instituto Chico Mendes de Conservação da Biodiversidade, ICMBIO.

SANTOS, A.J.B., BELLINI, C., VIEIRA, D.H.G., NETO, L.D. \& CORSO, G 2013. Northeast Brazil shows highest hawksbill turtle nesting density in the South Atlantic. Endanger. Species Res. 21: 25-32.

SANTOS, A.J.B., LIMA NETO, J.X., VIEIRA, D.H.G., DUTRA NETO, L., BELLINI, C., ALBUQUERQUE, N.S., CORSO, G. \& SOARES, B.L. 2016. Individual Nest Site Selection in Hawksbill Turtles Within and Between Nesting Seasons. Chelonian Conserv. Bi. 15 (1): 109-114.

SARAHAIZAD, M.S. \& SHAHRUL-ANUAR, M.S. 2014. Hatching success and nesting depth of Chelonia mydas (family: cheloniidae) in eggs relocation programme at Penang Island, Peninsular Malaysia. Malays. Appl. Biol. 43 (2): 59-70.

SEMINOFF, J.A. 2004. Southwest Fisheries Science Center, U.S. Chelonia mydas. The IUCN Red List of Threatened Species 2004: e.T4615A11037468. https://dx.doi.org/10.2305/IUCN.UK.2004.RLTS.T4615A11037468.en (last access in 31/05/2020).

SFORZA, R., MARCONDES, A.C.J. \& PIZETTA, G.T. 2017. Guia de Licenciamento Tartarugas Marinhas - Diretrizes para Avaliação e Mitigação de Impactos de Empreendimentos Costeiros e Marinhos. ICMBio, Brasília, pp 130.

SILVA,A.C.C.D., CASTILHOS, J.C., LOPEZ, G.G. \& BARATA, P.C.R. 2007. Nesting biology and conservation of the olive ridley sea turtle (Lepidochelys olivacea) in Brazil, 1991/1992 to 2002/2003. J. Mar. Biol. Assoc. UK. 87 (04): 1047-1056.

SIMÕES, T.N., SILVA, A.C., SANTOS, E.M. \& CHAGAS, C.A. 2014. Temperatura de incubação e razão sexual em filhotes recém-eclodidos da tartaruga marinha Eretmochelys imbricata (Linnaeus, 1766) no município do Ipojuca, Pernambuco, Brasil. Pap. Avulsos Zool. 54 (25): 363-374.

SOARES, U.M., ROSSETTI, E.L. \& CASSAB, R.C.T. 2003. Bacias sedimentares brasileiras. Bacia Potiguar. Fundação Paleontológica Phoenix. 56: 1-15.

SOARES, M.O., TEIXEIRA, C.E.P., BEZERRA, L.E.A., PAIVA, S.V., TAVARES, T.C.L, GARCIA, T.M., ARAÚJO, J.T., CAMPOS, C.C., FERREIRA, S.M.C., MATTHEWS-CASCON, H., FROTA, A., MONT'ALVERNE, T.C.F., SILVA, S.T., RABELO, E.F., BARROSO, C.X., FREITAS, J.E.P., JÚNIOR, M.M., CAMPELO, R.P.S., CAVALCANTE, R.M. 2020. Oil spill in South Atlantic (Brazil): environmental and governmental disaster. Mar. Policy. 115: 1-7.
SOUTO, M.V.S. 2009. Análise da evolução costeira do litoral setentrional do Estado do Rio Grande do Norte, região sob influência da indústria petrolífera. Tese de Doutorado, Universidade Federal do Rio Grande do Norte.

SOUZA-JUNIOR, E.M. 2014. Nidificação de Tartarugas Marinhas em Praias dos Municípios de Guamaré e Macau, RN. Trabalho de Conclusão de Curso, Instituto Federal de Educação, Ciência e Tecnologia do Rio Grande do Norte.

TESTA, V. \& BOSENCE, D.W.J. 1999. Physical and biological controls on the formation of carbonate and siliciclastic bedforms on the north-east Brazilian shelf. Sedimentology. 46 (2): 279-301.

TIWARI, M. \& BJORNDAL, K.A. 2000. Variation in morphology and reproduction in loggerheads, Caretta caretta, nesting in the United States, Brazil and Greece. Herpetologica. 56 (3): 343-356.

TOMILLO, P.S., SABA, V.S., BLANCO, G.S., STOCK, C.A., PALADINO, F.V. \& SPOTILA, J.R. 2012. Climate Driven Egg and Hatchling Mortality Threatens Survival of Eastern Pacific Leatherback Turtles. PLoS One. 7 (5): 1-7.

TOMILLO, P.S., GENOVART, M., PALADINO, F.V., SPOTILA, J.R. \& ORO, D. 2015. Climate Change Overruns Resilience Conferred by TemperatureDependent Sex Determination in Sea Turtles and Threatens their Survival. Glob. Change Biol. 21 (8): 2980-2988.

TOMILLO, P.S., FONSECA, L., PALADINO, F.V., SPOTILA, J.R. \& ORO, D. 2017. Are thermal barriers. PLoS One. 12 (5): 1-14.

VAN BUSKIRK, J. \& CROWDER, L.B. 1994. Life-History Variation in Marine Turtles. Copeia. 1994 (1): 66-81.

WALLACE, B.P., TIWARI, M. \& GIRONDOT, M. 2013. Dermochelys coriacea. The IUCN Red List of Threatened Species 2013: e.T6494A43526147. https://dx.doi.org/10.2305/IUCN.UK.2013- 2.RLTS.T6494A43526147.en (last access in 31/05/2020).

WEBB, G.J. \& COOPER-PRESTON, H. 1989. Effects of incubation temperature of crocodiles and the evolution of reptilian oviparity. Am. Zool. 29 (3): 953-971.

WHITING, S.D., LONG, J.L., HADDEN, K.M., LAUDER, A.D.K. \& KOCH, A.U. 2007. Insights into size, seasonality and biology of a nesting population of the Olive Ridley turtle in northern Australia. Wildlife. Res. 34 (3): 200-210.

WITHERINGTON, B. 1992. Behavioral responses of nesting sea turtles to articial lighting. Herpetologica. 48 (1): 31-39.

WITHERINGTON, B. \& FRAZER, N. 2003. Social and Economic Aspects of Sea Turtle Conservation. In The Biology of Sea Turtles (P. Lutz, J. Musick, J. Wyneken, eds). CRC marine science series, Boca Raton, Florida, p. 355-384.

ZÁRATE, P., BJORNDAL, K.A., DÍAZ, M.P., DUTTON, P.H., SEMINOFF, J.A. \& BOLTEN, A.B. 2013. Hatching and emergence success in green turtle Chelonia mydas nests in the Galápagos Islands. Aquat. Biol. 19: 217-229.

Received: 18/11/2020

Revised: 23/02/2021

Accepted: 06/04/2021

Published online: 30/04/2021 